\title{
MICROBIOLOGICAL CONTROL OF SOIL-BORNE ANTIBIOTIC RESISTANCE HUMAN PATHOGENS IN AGROECOSYSTEMS
}

\author{
Lyudmyla Symochko $^{1,2 *}$, Tamara Meleshko², Vitaliy Symochko³ ${ }^{3}$ Nadiya Boyko² \\ ${ }^{I}$ Department of Entomology and Biodiversity Conservation, Faculty of Biology, Uzhhorod National University, \\ Uzhhorod, Ukraine; \\ ${ }^{2}$ Research and Development Centre for Molecular Microbiology and Mucosal Immunology, Uzhhorod National \\ University, Uzhhorod, Ukraine; \\ ${ }^{3}$ Department of Horticulture and Viticulture, Faculty of Biology, Uzhhorod National University, Uzhhorod,
}

Ukraine;

*Corresponding author Lyudmyla Symochko ${ }^{1,2 *}$, email: lyudmilassem@ gmail.com;

Received May, 2018; Accepted May, 2018; Published June, 2018;

DOI: https://doi.org/10.31407/ijees8320

UOI license: http://u-o-i.org/1.01/ijees/86737318

\begin{abstract}
The spread of antibiotic-resistant microorganisms is one of the biggest problems, for the solution of which is necessary a detailed study of this process. We detected the presence of pathogenic bacteria in soil of agroecosystems of such medicinal plants: Mentha piperita, Inula helenium, Thymus serpillum, Rosa odorata and Calendula officinalis. A total of 106 isolates from soil of medicinal plants were examined for resistance to 9 antibiotics: lincomycin, oleandomycin, ampicillin, cefepime, ciprofloxacin, vancomycin, gentamicin, streptomicin, cefamandole. From all the above-mentioned ecosystems, antibiotic-resistant pathogenic microorganisms have been isolated. From soil with cultivated Thymus serpillum two bacterial strains: Serratia marcescens and Yersinia enterocolitica were resistant to majority of tested antibiotics. From the soil samples with cultivated Inula helenium 15 dominant bacterial strains were isolated. Pantoea agglomerans was one of the most antibiotics resistant bacteria among of others tested. Serratia odorifera biogroup 1 isolated from agroecosystem of Mentha piperita, was resistant to vancomycin, lincomycin, ampicillin and to cefepime. High level of antibiotic resistance was detected for Enterococcus faecalis and Bacillus cereus isolated from agroecosystems of Calendula officinalis and Rosa odorata were organic manure was used. The soil of agroecosystems, where medicinal plants are cultivated, is a source of antibiotic-resistant microorganisms pathogenic and conditionally pathogenic for humans.
\end{abstract}

Keywords: Soil, antibiotic resistance, bacteria, medicinal plants, pathogens, agroecosystems. 